\title{
Characteristics of DNA and Multiple rpoD Homologs of Microcystis (Synechocystis) Strains
}

\author{
TAKUYA SAKAMOTO, ${ }^{1}$ MAKOTO SHIRAI, ${ }^{1 *}$ MUNEHIKO ASAYAMA, ${ }^{1}$ TOKUJIRO AIDA, ${ }^{1}$ \\ AKIO SATO, ${ }^{1}$ KAN TANAKA $^{2}{ }^{2}$ HIDEO TAKAHASHI, ${ }^{2}$ AND MASAYASU NAKANO ${ }^{3}$ \\ Division of Biotechnology, Ibaraki University, Ami, Ibaraki 300-03, ${ }^{1}$ Institute of Applied Microbiology, \\ University of Tokyo, Bunkyo-ku, Tokyo $113,{ }^{2}$ and Department of Microbiology, \\ Jichi Medical School, Yakushiji, Tochigi 329-04, ${ }^{3}$ Japan
}

\begin{abstract}
The base compositions of DNAs from nine Microcystis strains, as determined by high-performance liquid chromatography, were 41 to $42 \mathrm{~mol} \% \mathrm{G}+\mathrm{C}$. Chromosomal DNAs derived from these strains were found to be extremely resistant to many restriction endonucleases, and a restriction analysis revealed the presence of a dam-like methylase or both dam- and $\mathrm{dcm}$-like methylases in all of the strains examined. Genomic Southern hybridization in which a synthetic oligonucleotide probe ( $r p o D$ probe) was used showed that members of the genus Microcystis might have multiple rpoD homologs, and the hybridization signal patterns observed with the DNAs of Microcystis aeruginosa strains were different from each other.
\end{abstract}

Members of the genus Microcystis are unicellular colonyforming cyanobacteria (blue-green algae) which produce surface blooms in eutrophic water; some strains have been found to possess a peptide toxin, microcystin $(13,19)$. The taxonomy of Microcystis species traditionally has been based on colony morphology and cell arrangement (10). However, these morphological features are easily changed in culture (16). Rippka proposed that, as prokaryotes, cyanobacteria are divisible into five major groups (sections) on the basis of culture characteristics (16), and Microcystis strains have been classified as members of the Microcystis cluster of the genus Synechocystis (26). At the present time, data for chemical, genetic, and physiological characteristics based on the use of axenic cultures are required for the taxonomy of cyanobacteria. The importance of $\mathrm{G}+\mathrm{C}$ contents in microbial classification has been established. However, the data available on the $\mathrm{G}+\mathrm{C}$ contents of Microcystis clones are limited. Chromosomal DNAs from different filamentous and unicellular cyanobacteria have been shown to be surprisingly resistant to cleavage by a number of restriction endonucleases $(5,11,15)$. This resistance could be due to the absence of specific sequences or to modification (methylation). Resistance of Microcystis DNAs to restriction endonuclease cleavage has been little examined. RNA polymerase holoenzymes contain the principal sigma factors that play a central role in the initiation of transcription (12). Tanaka et al. designed a synthetic oligonucleotide probe ( $r p o D$ probe) from an amino acid stretch conserved among the principal sigma factors in Escherichia coli and Bacillus subtilis (24) and, using it, detected four or five signals from the DNAs of Anabaena sp. strain PCC 7120, Synechococcus sp. strain PCC 7942, and Synechocystis sp. strain PCC 6803 by genomic Southern hybridization (23). Recently, we developed a technique for isolating axenic clones of Microcys$t$ tis by using a combination of the agarose plate technique and two-step centrifugation and isolated nine axenic Microcystis clones $(13,18,19)$. In this paper we describe the $\mathrm{G}+\mathrm{C}$ contents, restriction endonuclease cleavage characteristics, and multiple rpoD homologs of the DNAs of Microcystis isolates.

Cultures. Axenic Microcystis aeruginosa strains K-17,

\footnotetext{
* Corresponding author.
}

K-79, K-81, K-139, M-20, B-19, B-47, and S-77 and Microcystis viridis S-70 were isolated from Lake Kasumigaura, Ibaraki Prefecture, Japan $(13,18,19)$. Synechocystis sp. strain PCC 7820 was provided by R. Rippka (Pasteur Institut, Paris, France), and $M$. viridis NIES-102 was obtained from the Microbial Culture Collection of the National Institute for Environmental Studies, Tsukuba, Japan. All cyanobacterial strains were grown in CB medium under continuous illumination (19).

DNA extraction. Cells at the late logarithmic growth phase were sonicated for $10 \mathrm{~s}$ with a water bath type of sonicator ( $200 \mathrm{~W}, 36 \mathrm{kHz}$ ) to disrupt the gas vacuoles, spun down by centrifugation at $8,000 \times g$ for $10 \mathrm{~min}$, and then washed in TES buffer (0.05 M Tris- $\mathrm{HCl}, 0.1 \mathrm{M} \mathrm{NaCl}, 0.05 \mathrm{M}$ EDTA; $\mathrm{pH}$ 8.0). The washed cells (about $2 \mathrm{~g}$ [wet weight]) were resuspended in $5 \mathrm{ml}$ of SET buffer $(0.05 \mathrm{M}$ Tris- $\mathrm{HCl}, 0.05 \mathrm{M}$ EDTA, 25\% [wt/vol] sucrose; $\mathrm{pH} 8.0$ ) and centrifuged, and the resulting cell pellet was frozen at $-80^{\circ} \mathrm{C}$. After thawing at $30^{\circ} \mathrm{C}$, the cells were suspended in $4 \mathrm{ml}$ of SET buffer containing $8 \mathrm{mg}$ of lysozyme (Sigma) per $\mathrm{ml}$ and incubated at $37^{\circ} \mathrm{C}$ for $30 \mathrm{~min}$. The cells were lysed by adding $2 \%$ (final concentration) sodium dodecyl sulfate and incubating the preparation for $20 \mathrm{~min}$ at $60^{\circ} \mathrm{C}$. The DNA was extracted from each lysate with an equal volume of phenol-chloroform (1:1, $\mathrm{vol} / \mathrm{vol})$ and then with chloroform-isoamyl alcohol $(24: 1$, $\mathrm{vol} / \mathrm{vol}$ ). After the DNA was recovered by ethanol precipitation, it was incubated in $2 \mathrm{ml}$ of TE buffer $(10 \mathrm{mM}$ Tris-HCl, $1 \mathrm{mM}$ EDTA; pH 8.0) containing $200 \mu \mathrm{g}$ of pancreatic RNase (Sigma) at $37^{\circ} \mathrm{C}$ for $30 \mathrm{~min}$. After phenol and chloroform-isoamyl alcohol extractions, the DNA was spooled onto a glass rod during ethanol precipitation and rinsed with $70 \%$ ethanol. The spooled DNA was suspended in TE buffer and dialyzed against the same buffer. The UV absorbance spectra between 190 and $300 \mathrm{~nm}$ were as predicted for high-purity nucleic acid, and the ratios of $A_{260}$ to $A_{280}$ were 1.8 to 2.0 .

DNA base composition. DNAs were hydrolyzed with nuclease P1 by using a DNA-GC kit (Yamasa Shoyu Co., Ltd., Choshi, Japan) (27). The standard solution and hydrolysate were analyzed with a Nihon Bunko high-performance liquid chromatography system (model 880 pump and model $875 \mathrm{UV}$ detector; Nihon Bunko Co., Ltd., Tokyo, Japan) by using a Inertosil octyldecyl silane column (250 by $4.6 \mathrm{~mm}$; GL Sciences, Inc., Tokyo, Japan) and $0.2 \mathrm{M}$ ammonium dihy- 
TABLE 1. DNA base compositions and restriction enzyme cleavage of Microcystis strains

\begin{tabular}{|c|c|c|c|c|c|c|c|c|c|c|c|c|}
\hline \multirow{2}{*}{$\begin{array}{l}\text { Restriction } \\
\text { enzyme }\end{array}$} & \multirow{2}{*}{$\begin{array}{l}\text { Recognition } \\
\text { sequence }^{a}\end{array}$} & \multicolumn{8}{|c|}{ M. aeruginosa strains $^{b}$} & \multicolumn{2}{|c|}{ M. viridis strains } & \multirow{2}{*}{$\begin{array}{l}\text { Synechocysti } \\
\text { sp. strain } \\
\text { PCC } 7820\end{array}$} \\
\hline & & K-17 & K-79 & K-81 & K-139 & B-19 & B-47 & S-77 & $\mathrm{M}-20$ & S-70 & NIES-102 & \\
\hline & $\mathbf{M}$ & & & & & & & & & & & \\
\hline Dpn I & GATC & + & + & + & + & + & + & + & + & + & NT & NT \\
\hline MboI & $\underset{+}{G A T C}$ & - & - & - & - & - & - & - & - & - & NT & NT \\
\hline Sau3AI & GATC & + & + & + & + & + & + & + & + & + & NT & NT \\
\hline Bst NI & $\mathrm{CC}_{\mathrm{T}}^{\mathrm{A}} \mathrm{GG}$ & + & + & + & + & + & + & + & + & + & NT & NT \\
\hline EcoRII & $\stackrel{C}{\mathrm{C}}_{\mathrm{T}}^{\mathrm{A}} \mathrm{GG}$ & - & - & - & + & + & + & + & + & + & NT & NT \\
\hline Bam $\mathrm{HI}$ & GGATCC & - & - & - & - & - & - & - & - & - & NT & NT \\
\hline BglII & AGÅTCT & - & - & - & - & - & - & - & - & - & NT & NT \\
\hline$E c o$ RI & $\underset{+}{G A A T C C}$ & - & - & - & - & - & - & - & - & - & NT & NT \\
\hline HindIII & ${ }_{+}^{+} \mathrm{AGCT}_{+}^{+}$ & + & + & + & + & + & + & + & + & + & NT & NT \\
\hline PstI & CTGCA & - & - & - & - & - & - & - & - & - & NT & NT \\
\hline SalI & $\underset{+}{\mathrm{GT}} \stackrel{\stackrel{+}{\mathrm{C}} \mathrm{G}}{+} \mathrm{AC}$ & - & - & - & - & - & - & - & - & - & NT & NT \\
\hline Sma I & $\stackrel{+}{\mathrm{C} C} \stackrel{+}{\mathrm{C}} \mathrm{CGGG}$ & - & - & - & - & - & - & - & - & - & NT & NT \\
\hline$X b a \mathrm{I}$ & TCTAGA & + & + & + & + & + & + & + & + & + & NT & NT \\
\hline
\end{tabular}

${ }^{a}$ Recognition sequences are specified for the $5^{\prime} \rightarrow 3^{\prime}$ strand. ${ }_{A}^{+}$or ${ }_{C}^{+}$, inhibition of an endonuclease by a methyladenine or methylcytosine residue within the recognition sequence; $\stackrel{\mathrm{A}}{\mathrm{A}}$, methyladenine residues are a prerequisite for the activity of DpnI; $\AA$ or $\mathcal{C}$, digestion of the DNA which is not influenced by methyladenine or methylcytosine residues. SmaI cuts $\mathrm{C}^{\mathrm{m} 5} \mathrm{CCGGG}$ but not $\mathrm{C}^{\mathrm{m} 4} \mathrm{CCGGG}$ (m5, 5-methylcytosine; m4, 4-methylcytosine). If an adenine or cytosine residue is not identified by a symbol, the influence of methylation on the restriction activity is not known (17), +, cleaved; -, not cleaved; NT, not tested.

${ }^{b}$ The $\mathrm{G}+\mathrm{C}$ contents of $M$. aeruginosa $\mathrm{K}-17, \mathrm{~K}-79, \mathrm{~K}-81, \mathrm{~K}-139, \mathrm{~B}-19, \mathrm{~B}-47, \mathrm{~S}-77$, and M-20 are $42,41,41,41,41,42,42$, and 41 mol\%, respectively; the G+C contents of $M$. viridis S-70 and NIES-102 are 42 and 41 mol\%, respectively; and the G+C content of Synechocystis sp. strain PCC 7820 is 42 mol\%.

drogen phosphate as the mobile phase. The various Microcystis strains examined had fairly similar base compositions ( 41 to $42 \mathrm{~mol} \% \mathrm{G}+\mathrm{C}$ ), and there was no difference in $\mathrm{G}+\mathrm{C}$ content between $M$. aeruginosa and $M$. viridis (Table 1). All measurements of $\mathrm{G}+\mathrm{C}$ content used were mean values obtained from at least three individual digestions of DNA. The average, maximum, and minimum values were 0.92 , 0.98 , and 0.88 , respectively, for the $\mathrm{A} / \mathrm{T}$ ratio, $1.04,1.08$, and 1.00 , respectively, for the $\mathrm{G} / \mathrm{C}$ ratio, and $0.97,1.00$, and 0.94 , respectively, for the purine/pyrimidine ratio. These ratios suggest that the analytical method used was adequate for estimating the $\mathrm{G}+\mathrm{C}$ contents of DNAs (7). The $\mathrm{G}+\mathrm{C}$ content of the Escherichia coli K-12 DNA used as a control was 51 mol\%, in agreement with the value reported previously (14). The G+C content of Synechocystis sp. strain PCC 7005 (Microcystis cluster) has been reported to be 45 mol\% (26). Recently, Fahrenkug et al. reported that the $\mathrm{G}+\mathrm{C}$ contents calculated from the $50 \%$ thermal denaturation temperature
(A)

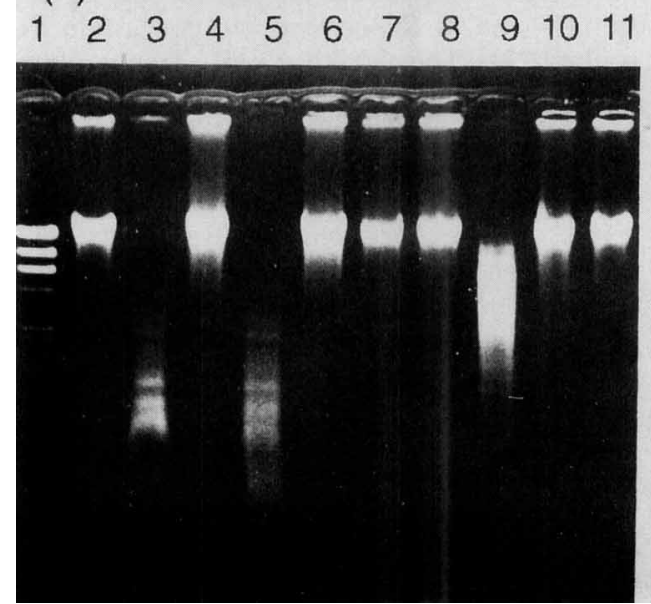

(B)

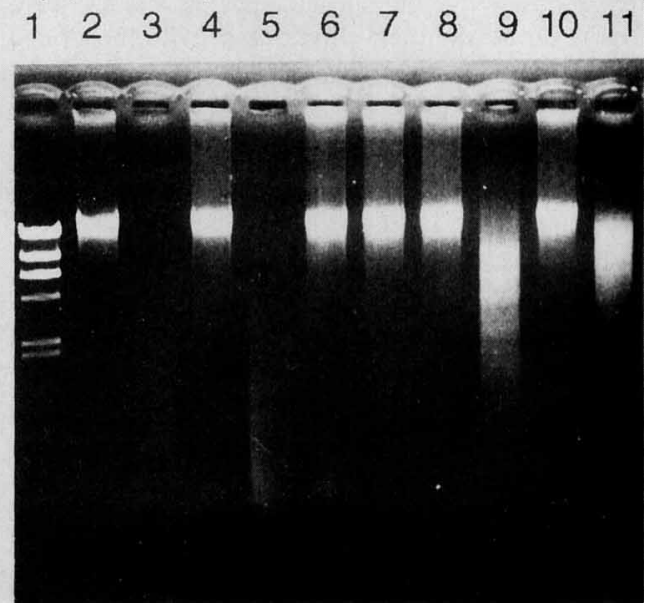

FIG. 1. Restriction analysis of chromosomal DNAs prepared from $M$. aeruginosa K-81 (A) and S-77 (B). The DNA ( $2 \mu \mathrm{g}$ in $20 \mu \mathrm{l}$ of buffer) was digested with an enzyme (10 to $40 \mathrm{U}$ per $\mu \mathrm{g}$ of DNA) for $3 \mathrm{~h}$ at each optimum temperature, and the restricted DNA was analyzed by electrophoresis on an $0.8 \%$ agarose gel. Lanes 1, HindIII digest of DNA (molecular weight markers); lanes 2, untreated DNA; lanes 3, DpnI digests; lanes 4, MboI digests; lanes 5, Sau3AI digests; lanes 6, Bam HI digests; lanes 7, PstI digests; lanes 8, SalI digests; lanes 9, HindIII digests; lanes 10, EcoRI digests; lanes 11, EcoRII digests. 
(A)
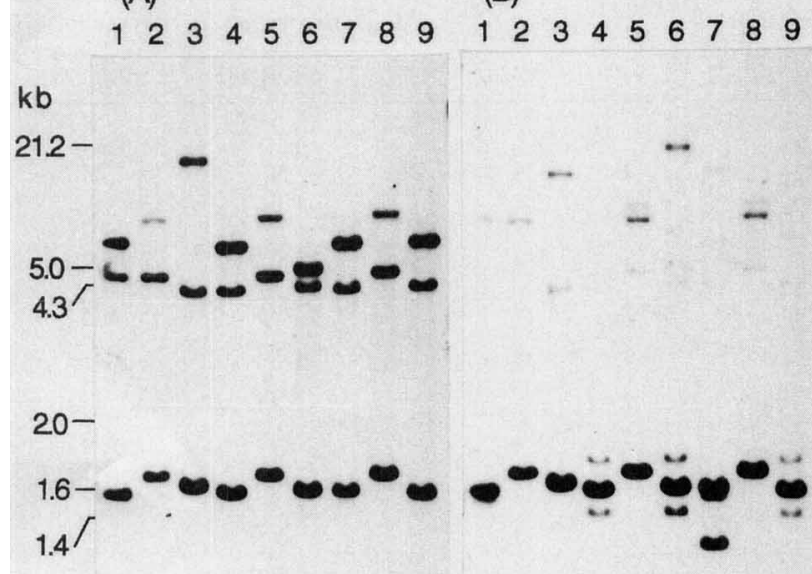

(C)

(D)

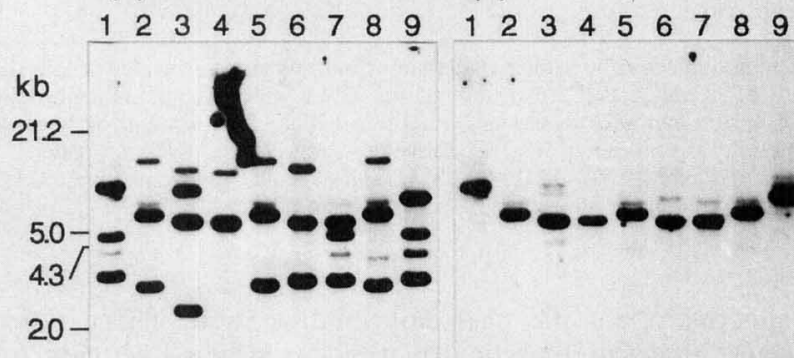

FIG. 2. Southern hybridization analyses of genomic DNAs from Microcystis strains performed with the ${ }^{32} \mathrm{P}$-labeled $r p o D$ probe (A and C) and the ${ }^{32} \mathrm{P}$-labeled rpoD1 gene of Synechococcus sp. strain PCC 7942 (B and D). The DNAs in panels A and B were digested with $X b a \mathrm{I}$, and the DNAs in panels $C$ and D were digested with HindIII. After DNA blotting, the filters used in panels $A$ and $C$ were washed to remove the probe and then rehybridized with the cloned 2.4-kb EcoRI fragment containing the rpoD1 gene of Synechococcus sp. strain PCC 7942 (panels B and D). All lanes except lanes 4 contained strains of $M$. aeruginosa; lanes 4 contained a strain of $M$. viridis. Lanes 1, strain K-139; lanes 2, strain K-17; lanes 3, strain B-19; lanes 4, strain S-70; lanes 5, strain K-81; lanes 6, strain M-20; lanes 7, strain B-47; lanes 8, strain K-79; lanes 9, strain S-77.

data for Microcystis sp. strains P1-15, C3-40, C5-34, and AK1-6 were $38,41,41$, and $43 \mathrm{~mol} \%$, respectively (3). Both these data and our results show that the $\mathrm{G}+\mathrm{C}$ contents of all currently characterized Microcystis strains range from 38 to $45 \mathrm{~mol} \%$.

Cleavage of Microcystis DNAs by restriction endonucleases. DNAs of Microcystis isolates were treated with type II restriction endonucleases and analyzed by gel electrophoresis (Fig. 1) (17). The DNAs were found to be fully resistant to a number of restriction endonucleases (Table 1 ). The presence of $d a \mathrm{~m}$ - and $\mathrm{dcm}$-like methylases or site-specific methylase counterparts of the restriction systems in some cyanobacterial strains has been reported previously $(2,5,11,15,25)$.
Since the DNAs of all nine Microcystis strains were hydrolyzed by $D p n I$ and Sau3AI, but not by $M b o I$, dam-like methylases may be present in these strains (4). The results of a cleavage analysis of the DNAs in which two isoschizomeric enzymes, Bst NI and EcoRII, were used suggested that $M$. aeruginosa K-17, K-79, and K-81 had dcm-like methylases. Since restriction endonuclease activities were detected in these Microcystis strains (data not shown), members of the genus Microcystis might have site-specific methylase counterparts of the restriction system. On the other hand, the chromosomal DNA of an Anabaena strain might lack the recognition sites for certain endonucleases (6). However, it is not known whether the present members of the genus Microcystis lack some endonuclease recognition sites.

Multiple $r p o D$ homologs. Southern hybridization with the $r p o D$ probe (5'GCTTGICIIATCCACCAIGTIGCITAIGT3') was performed as described previously $(23,24)$. A $20-\mu \mathrm{g}$ portion of chromosomal DNA was completely digested with the restriction endonuclease, and the restricted DNA was analyzed by electrophoresis in an $0.8 \%$ agarose gel ( 13.5 by $13.5 \mathrm{~cm}$ ). Three signals were detected in every $X b a \mathrm{I}$-cleaved DNA sample, and three to five signals, including weak signal bands, were detected in HindIII-cleaved DNAs (Fig. 2A and C). Most of the hybridization signal patterns were different from each other; the exceptions were the patterns of $M$. aeruginosa K-17, K-79, and K-81. The signal patterns of both XbaI- and HindIII-cleaved DNAs of strains K-17, $\mathrm{K}-79$, and K-81 were extremely similar. We are currently cloning and sequencing the DNA regions corresponding to the hybridization signals (1). Our results indicate that $M$. aeruginosa K-81 has at least four $r p o D$ homologous genes. Four or five Southern hybridization signals with the rpoD probe were detected with the DNAs of the following three cyanobacterial strains: Anabaena sp. strain PCC 7120, Synechococcus sp. strain PCC 7942, and Synechocystis sp. strain PCC 6803 (low-G+C-content cluster) (23). The putative products of four rpoD-related genes of Synechococcus sp. strain PCC 7942 were very similar in basic structure to the principal sigma factors of eubacterial strains (23). Furthermore, one of the four $r p o D$-related genes ( $r p o D 1)$ was very similar to the $\operatorname{sig} A$ gene of Anabaena sp. strain PCC 7120 and might be the functional homolog of the principal sigma factors (22). Therefore, Southern hybridization was performed with a 2.4-kb EcoRI fragment containing the rpoD1 gene of Synechococcus sp. strain PCC 7942 as the probe (23). The 2.4-kb EcoRI fragment exhibited strong hybridization with one of the $r p o D$ homologs from each Microcystis DNA digested with $X b a$ I or HindIII (Fig. 2B and D). These observations indicate that one of the rpoD homologs of Microcystis strains was highly homologous with rpoD1 of Synechococcus sp. strain PCC 7942. The results of a Southern hybridization analysis in which the $r p o D$ probe was used suggest that cyanobacteria may generally have multiple $r p o D$ homologs. However, the biological role of each $r p o D$ homolog is not known.

The differences in the hybridization signal patterns among $M$. aeruginosa strains indicate that the genotypes of these strains may differ from each other. An analysis of alloenzyme divergence performed by Kato et al. showed that $M$. aeruginosa was highly polymorphic and that there were 12 different genotypes among the 19 strains examined (8). Furthermore, these authors reported that two morphotypes (large and small cell types) were recognized in $M$. aeruginosa on the basis of differences in average cell size and colony formation (8). On the other hand, Komárek reported that some strains of $M$. aeruginosa identified by Kato et al. 
should belong to Microcystis ichthyoblabe on the basis of light microscopic features (9). Thus, the taxonomy of the genus Microcystis remains confused. Tanaka found that the signal patterns of the chromosomal DNA digests of 12 Streptomyces species after Southern hybridization with the $r p o D$ probe were different from each other, but that those of Streptomyces lividans 66 and Streptomyces coelicolor A3(2), which is very closely related to $S$. lividans, were identical (21). Southern hybridization analysis in which the rpoD probe is used may thus be useful for the identification and classification of cyanobacterial species.

We thank Rosmarie Rippka for strain PCC 7820.

This work was supported by a Grant-in-Aid for Science Research from the Ministry of Education, Science, and Culture of Japan.

\section{REFERENCES}

1. Asayama, M., M. Shirai, A. Sato, T. Aida, and M. Nakano. Unpublished data.

2. Barbeyron, T., K. Kean, and P. Forterre. 1984. DNA adenine methylation of GATC sequences appeared recently in the Escherichia coli lineage. J. Bacteriol. 160:586-590.

3. Fahrenkrug, P. M., M. B. Bett, and D. L. Parker. 1992. Base composition of DNA from selected strains of the cyanobacterial genus Microcystis. Int. J. Syst. Bacteriol. 42:182-184.

4. Gingeras, T. R. 1991. Restriction-modification systems: genetic sentries and useful systems in the study of molecular genetics, p. 301-321. In U. N. Streips and R. E. Yasbin (ed.), Modern microbial genetics. John Wiley \& Sons, Inc., New York.

5. Gomez-Eichelmann, M. C., A. Levy-Mustri, and J. RamirezSantos. 1991. Presence of 5-methylcytosine in CC(A/T)GG sequences (Dcm methylation) in DNAs from different bacteria. $\mathbf{J}$. Bacteriol. 173:7692-7694.

6. Herrero, A., J. Elhai, B. Hohn, and C. P. Wolk. 1984. Infrequent cleavage of cloned Anabaena variabilis DNA by restriction endonucleases from $A$. variabilis. J. Bacteriol. 160:781-784.

7. Katayama-Fujimura, Y., Y. Komatsu, H. Kuraishi, and T. Kaneko. 1984. Estimation of DNA base composition by high performance liquid chromatography of its nuclease P1 hydrolysate. Agric. Biol. Chem. 48:3169-3172.

8. Kato, T., M. F. Watanabe, and M. Watanabe. 1991. Allozyme divergence in Microcystis (Cyanophyceae) and its taxonomic inference. Arch. Hydrobiol. Suppl. 92:129-140.

9. Komárek, J. 1991. A review of water-bloom forming Microcys tis species, with regard to populations from Japan. Arch. Hydrobiol. Suppl. 92:115-127.

10. Komárek, J., and K. Anagnostidis. 1986. Modern approach to the classification system of cyanophytes. II. Chroococcales. Arch. Hydrobiol. Suppl. 73:157-226.

11. Lambert, G. R., and N. G. Carr. 1984. Resistance of DNA from filamentous and unicellular cyanobacteria to restriction endonuclease cleavage. Biochim. Biophys. Acta 781:45-55.

12. Lewin, B. 1990. Genes IV, p. 214-239. Oxford University Press, Oxford.
13. Ohtake, A., M. Shirai, T. Aida, N. Mori, K. Harada, K. Matsuura, M. Suzuki, and M. Nakano. 1989. Toxicity of Microcystis species isolated from natural blooms and purification of the toxin. Appl. Environ. Microbiol. 55:3202-3207.

14. Orskov, F. 1984. Genus I. Escherichia Castellani and Chalmers $1919,941^{\mathrm{AL}}$, p. $420-423$. In N. R. Krieg and J. G. Holt (ed.) Bergey's manual of systematic bacteriology, vol. 1. The Williams \& Wilkins Co., Baltimore.

15. Padhy, R. N., F. G. Hottat, M. M. Coene, and P. P. Hoet. 1988 . Restriction analysis and quantitative estimation of methylated bases of filamentous and unicellular cyanobacterial DNAs. J. Bacteriol. 170:1934-1939.

16. Rippka, R. 1988. Recognition and identification of cyanobacteria. Methods Enzymol. 167:28-67.

17. Sambrook, J., E. F. Fritsch, and T. Maniatis. 1989. Molecular cloning: a laboratory manual, 2nd ed., p. 5.3-5.32. Cold Spring Harbor Laboratory Press, Cold Spring Harbor, N.Y.

18. Shirai, M., K. Matsumaru, A. Ohtake, Y. Takamura, T. Aida, and M. Nakano. 1989. Development of a solid medium for growth and isolation of axenic Microcystis strains (cyanobacteria). Appl. Environ. Microbiol. 55:2569-2571.

19. Shirai, M., A. Ohtake, T. Sano, S. Matsumoto, T. Sakamoto, A. Sato, T. Aida, K. Harada, T. Shimada, M. Suzuki, and M. Nakano. 1991. Toxicity and toxins of natural blooms and isolated strains of Microcystis spp. (cyanobacteria) and improved procedure for purification of culture. Appl. Environ. Microbiol. 57:1241-1245.

20. Sugimoto, Y., K. Tanaka, S. Masuda, and H. Takahashi. Submitted for publication.

21. Tanaka, K. 1988. Ph.D. thesis. University of Tokyo, Tokyo, Japan.

22. Tanaka, K., S. Masuda, and H. Takahashi. 1992. The complete nucleotide sequence of the gene ( $r p o D 1)$ encoding the principal o factor of the RNA polymerase from the cyanobacterium Synechococcus sp. strain PCC7942. Biochim. Biophys. Acta 1132:94-96.

23. Tanaka, K., S. Masuda, and H. Takahashi. 1992. Multiple rpoD-related genes of cyanobacteria. Biosci. Biotech. Biochem. 56:1113-1117.

24. Tanaka, K., T. Shiina, and H. Takahashi. 1988. Multiple principal sigma factor homologs in eubacteria: identification of the "rpoD box." Science 242:1040-1042.

25. van den Hondel, C. A. M. J. J., R. W. van Leen, G. A. van Arkel, M. Duyvesteyn, and A. de Waard. 1983. Sequence-specific nucleases from the cyanobacterium Fremyella diplosiphon, and a peculiar resistance of its chromosomal DNA towards cleavage by other restriction enzymes. FEMS Microbiol. Lett. 16:7-12.

26. Waterbury, J. B., and R. Rippka. 1989. Subsection I. Order Chroococcales Wettstein 1924 Emend. Rippka et al. 1979, p. 1728-1746. In J. T. Staley, M. P. Bryant, N. Pfennig, and J. G. Holt (ed.), Bergey's manual of systematic bacteriology, vol. 3. The Williams \& Wilkins Co., Baltimore.

27. Yamasa Shoyu Co. 1986. Yamasa biochemicals for research. Yamasa Shoyu Co. Ltd., Chosi, Japan. 